\title{
Entrepreneurship Orientation, Eco-innovation, Information and Communication Technology (ICT) Learning Adoption Capability: A case Study of Food SME's in Central Java, Indonesia.
}

\author{
Vincent Didiek Wiet Aryanto ${ }^{1, *}$, Kunio Kondo ${ }^{2}$, Yohan Wismantoro ${ }^{3}$, and \\ Pulung Nurtantyo Andono ${ }^{4}$ \\ ${ }^{1}$ Graduate School of Business Management, Universitas Dian Nuswantoro, Jl. Imam Bonjol No. 207, \\ Semarang 50131, Indonesia \\ ${ }^{2}$ School of Media Science, Tokyo University of Technology Hachioji Campus Tokyo 192-0982 Japan \\ ${ }^{3}$ Department of Management, Faculty of Economics and Business, Universitas Dian Nuswantoro, \\ Jl. Nakula 1 No.5-11 Semarang 50131, Indonesia. \\ ${ }^{4}$ Faculty of Computer Science, Universitas Dian Nuswantoro, Jl. Nakula I No. 5-11, \\ Semarang 50131, Indonesia
}

\begin{abstract}
This study aimed to investigate the entrepreneurship orientation among the Central Java's food small and medium enterprises (SMEs) and its impact on their marketing performance, the business method through eco-innovation. This study also employed eco-innovation and Information and Communication Technology (ICT) learning adoption capability. The respondents of this study were withdrawn purposely from food industries located in Central Java. The location of the study was in Surakarta, Salatiga, Semarang and Kudus. The time frame of the study was from January 2019 to July 2019. The software of SEM version 23 (Structural Equation Modelling) was utilized to test the hypotheses. The findings revealed that all the hypotheses (entrepreneurship orientation, ecoinnovation and ICT learning adoption capability) have significant impact on marketing performance.
\end{abstract}

Keywords: Food industries, green company, marketing performance

\section{Introduction}

Previous studies revealed that there are relationships between entrepreneurship orientation and marketing performance, those connections are moderated by green company or ecoinnovation performance $[1,2]$. In contrast, some studies reveal that entrepreneurship orientation does not have a relationship with the company performance and marketing performance $[3,4]$. Therefore this study proposed eco-innovation to mediate between entrepreneurship orientation and marketing performance. According to Bagaria et al. the implementation of eco-innovation in food industries can improve food storage technology; introduce energy efficient, low carbon waste and food chain supply; refine processing method to lessen the loss of raw materials; and improve organizational eco-innovation to save food waste cost [5].

The indicators of entrepreneurship orientation both of internal and external locus of control can be elaborated as risk taker, proactive action, aggressive and competitive action

\footnotetext{
* Corresponding author: vincentaryanto@dsn.dinus.ac.id
} 
[6-8]. Entrepreneurship orientation also incorporates cultural development, new product and service development, technological advancement and green business issues [1,9]. Entrepreneurship orientation does not only deal with the individual entrepreneur per se, but also deals with the business environment influencing the entrepreneurs.

The eco-innovation is a method based on life-cycle and value added innovation activities incorporating technology-based products as well as non-technology products. The production processes, management, services, and new way of business are manifested in the use of life cycle assessment to result in minimizing risk of pollution, including negative impact in using resources and energy $[1,10]$. Furthermore, the researchers stated that ecoinnovation consists of organization novelty that has less negative impact on the environment such as change in values, beliefs, norms, knowledge and management activities including change in administration, institutions, regulation and governance systems.

Marketing performance is a part of company performance to aim at augmenting efficiency of the organization. Marketing performance includes sales growth, market share growth, revenue growth, profitability and stock returns. Marketing performance has the dimension of culture, capabilities, process, market performance and financial performance [11].

Information and communication technology (ICT) has enabled to boost firm organization performance. Yunis et al. consider the corporate entrepreneurship influence on firm and marketing performance [12]. Furthermore, the ICT utilization has improved the company's competitiveness. The utilization and adoption of ICT has enhanced the innovative use of company resources. This study was supported by Adamides and Karacapilidis that revealed the utilization of ICT has two dimensions either strategic and operational [13]. Thus, organizations must prepare for the human resources to integrate ICT aspects on their organizational design and planning.

\section{Materials and methods}

This research utilized a purposive survey method to withdraw from the population of food industries in Central Java. The respondents were those who apply some sort of ecoinnovation activities on their business and marketing performance particularly in the level of Small and Medium Enterprises (SMEs). Food related industries were considered to be the respondents considering their rapid growth and self-sustained existence during the financial crisis.

\subsection{Entrepreneurship orientation}

Entrepreneurship orientation is a process of organizational learning capabilities. Previous studies reveal that there are two approaches for conceptualizing entrepreneurship orientation such as composite dimension and unidimensional approach portrayed by risk taking behavior, innovative behavior and proactive behavior [14, 15]. Another study undertaken by Zhang et al. confirms that those three aspects of entrepreneurship's unidimensional approach have significant and positive impact on marketing performance [16]. In addition, the researchers suggest having better direct influence between entrepreneurship orientations and marketing performance. Fernando \& Wah stated that the implementation of eco-innovation towards marketing and firm performance in Malaysia, the firm marketing performance on harmonizing environmental, economic and social performance [17]. The application of eco-innovation has boosted the firm's product quality and production efficiency. 
There were two hypothesis applied in this study,

H1: Entrepreneurship Orientation has positive and significant impact on eco-innovation.

$\mathrm{H} 2$ : Entrepreneurship Orientation has a positive and significant impact on marketing performance.

\subsection{ICT learning capability}

Previous studies reveal that the use of ICT improves eco-innovation and firm performance significantly; furthermore the use of ICT enhances the organization performance $[1,18$, 19]. The adoption of ICT plays an imperative role in promoting a firm's marketing performance. However in the case of Indonesia, Fernando et al. emphasize the use of ICT as the online green network to improve the application of eco-innovation and firm performance since the online green network is considered as the weakness implementation of eco-innovation in Indonesia [17]. ICT learning capability goes hand in hand with the organizational learning capability. It deals as the basis of a managerial approach to bolster learning within an organization. The organizational learning has useful impacts on firm performance [20].

H3: ICT learning capability has positive and significant impact on eco-innovation.

H4: ICT learning capability has a positive and significant impact on marketing performance.

\subsection{Eco-Innovation}

The innovation capability is the key point of long-period success in business, especially in markets and companies which have capability to innovate and be able to react to challenges of market changes faster and are capable to exploit products and market opportunities [21]. Most of the eco-innovation studies emphasize on describing company performance rather than firm's marketing performance. Fernando et al. explore the application of ecoinnovation in Indonesia's furniture industry, in addition their findings the importance of online green network, the implementation of eco-innovation has significant impact on firm performance and sustainable business practices despite the shortage of government initiatives and support [22]. This research is supported by Jogaratnam et al. that enhancing business performance in Taiwan requires a successful application of eco-innovation [23]. Other studies also reveal that integrating eco-innovation in firm strategy is able to enhance the firm's marketing performance $[1,24]$.

H5: Eco-innovation has a positive and significant impact on marketing performance.

\subsection{Sample size}

This research was done by collecting 190 respondents in central Java particularly in the city of Surakarta, Salatiga, Semarang and Kudus to test the proposed model of hypotheses. Technique of sampling used purposive to address the food industries that has applied some sort of elements of eco-innovation. The operationalized variables were depicted as in table 1 as follows:

Table 1. Construct measurement

\begin{tabular}{|l|l|l|}
\hline \multicolumn{1}{|c|}{ Variable } & \multicolumn{1}{|c|}{ Concept Definition } & \multicolumn{1}{c|}{ Authors } \\
\hline $\begin{array}{l}\text { Entrepreneurship Orientation } \\
\text { Risk taking behavior } \\
\begin{array}{l}\text { Proactive behavior } \\
\text { Innovative behavior }\end{array}\end{array}$ & $\begin{array}{l}\text { Getting to know the direct } \\
\text { impact to the firm marketing } \\
\text { strategy }\end{array}$ & $\begin{array}{l}\text { Shan et al. [7] } \\
\text { Zhang et al. [16] } \\
\text { Linton \& Kask [8] }\end{array}$ \\
\hline
\end{tabular}

(Continued on next page) 
Table 1. Continued

\begin{tabular}{|c|c|c|}
\hline Variable & Concept definition & Authors \\
\hline $\begin{array}{l}\text { ICT learning } \\
\text { capability } \\
\text { IT utilization } \\
\text { ICT-based } \\
\text { knowledge. } \\
\text { Managerial } \\
\text { commitment }\end{array}$ & $\begin{array}{l}\text { The utilization of ICT to enable the } \\
\text { organization learning capability and } \\
\text { improve the firm marketing } \\
\text { performance. }\end{array}$ & $\begin{array}{l}\text { Buttol et al. [18] } \\
\text { Alegre et al. [20] } \\
\text { Green et al. [19] } \\
\text { Aryanto et al. [2] }\end{array}$ \\
\hline $\begin{array}{l}\text { Eco-innovation } \\
\text { Green } \\
\text { innovation } \\
\text { Green food } \\
\text { storage } \\
\text { technology. } \\
\text { Energy } \\
\text { efficiency } \\
\text { Food waste } \\
\text { saving food } \\
\text { Green } \\
\text { network }\end{array}$ & $\begin{array}{l}\text { The definition of eco-innovation is a } \\
\text { method of life-cycle basis and value } \\
\text { added basis on innovation activities } \\
\text { to incorporate whether technology- } \\
\text { based product as well as non- } \\
\text { technology product. The production } \\
\text { process, management, services, and } \\
\text { new way of business are manifested } \\
\text { in the use of life cycle assessment to } \\
\text { result in minimizing risk of pollution } \\
\text { including risk of impact negatively in } \\
\text { using resources and energy resources. }\end{array}$ & $\begin{array}{l}\text { Bagaria et al. [5] } \\
\text { Aryanto et al. [2] } \\
\text { Jogaratnam et al. [23] } \\
\text { Hojnik [24] }\end{array}$ \\
\hline $\begin{array}{l}\text { Marketing } \\
\text { performance } \\
\text { Sales growth } \\
\text { Market share } \\
\text { Customer } \\
\text { retention } \\
\text { Marketing profit }\end{array}$ & $\begin{array}{l}\text { Marketing performance is a part of } \\
\text { company performance to aim at } \\
\text { augmenting efficiency of the } \\
\text { organization. Marketing performance } \\
\text { includes sales growth, market share } \\
\text { growth, revenue growth, profitability } \\
\text { and stock returns. Marketing } \\
\text { performance has the dimension of } \\
\text { culture, capabilities, process, market } \\
\text { performance and financial } \\
\text { performance }\end{array}$ & $\begin{array}{l}\text { Aryanto et al. [2] } \\
\text { Pimenta de Gama [11] }\end{array}$ \\
\hline
\end{tabular}

\subsection{Measure instrument}

Entrepreneurship orientation variable was measured by three items such as risk taking behavior, proactive behavior and innovative behavior. ICT learning capability was measured by three items such as IT utilization, ICT-based knowledge, and managerial commitment. In addition, Eco-innovation was measured by five items such as green innovation, green food storage technology, energy efficiency, food waste saving and green food network. Finally, the marketing performance variable was measured by four items that were composed of sales growth, market share, customer retention and marketing profit. Research instrument was used by a 7-point scale.

\section{Results and discussion}

Analysis of the full structural model was undertaken by using SEM-AMOS version 23, H1 mentioned the relationship between entrepreneurship orientation and eco-innovation, the result showed that $\mathrm{cr}=2.182$ and probability is 0.46 . $\mathrm{H} 2$ mentioned the relationship 
between entrepreneurship orientation to marketing performance, the result showed that $\mathrm{cr}=2.024$ and probability is 0.42 . H3 mentioned the relationship between ICT learning adoption capability and eco-innovation, the result showed that $\mathrm{cr}=3.094$ and probability is 0.02. H4 mentioned the relationship between ICT learning adoption capability and marketing performance, the result showed that $\mathrm{cr}=2.505$ and probability is 0.11 . H5 mentioned the relationship between eco-innovation and marketing performance, the result showed that $\mathrm{cr}=2.251$ and probability $=0.023$. The conclusion was all hypotheses were accepted considering that all cr values $>2$ (Table 2).

Table 2. Hypotheses

\begin{tabular}{|c|c|c|c|c|c|}
\hline Hypotheses & Estimate & S.E & CR & P & Conclusion \\
\hline $\begin{array}{c}\text { H1:Entrepreneurship orientation to } \\
\text { eco-innovation }\end{array}$ & 0.195 & 0.98 & 2.182 & 0.46 & Accepted \\
\hline $\begin{array}{c}\text { H2:Entrepreneurship orientation to } \\
\text { marketing performance. }\end{array}$ & 0.167 & 0.82 & 2.024 & 0.42 & Accepted \\
\hline $\begin{array}{c}\text { H3:ICT learning adoption capability } \\
\text { to eco-innovation }\end{array}$ & 0.348 & 0.112 & 3.094 & 0.02 & Accepted \\
\hline $\begin{array}{c}\text { H4:ICT learning adoption capability } \\
\text { to marketing performance }\end{array}$ & 0.242 & 0.096 & 2.505 & 0.11 & Accepted \\
\hline $\begin{array}{c}\text { H5:Eco-innovation to marketing } \\
\text { performance }\end{array}$ & 0.155 & 0.068 & 2.251 & .023 & Accepted \\
\hline
\end{tabular}

Significant at $\mathrm{p} \leq 0.05$

The study found out that entrepreneurship orientation has significant and positive impact on eco-innovation, the entrepreneurs awareness towards the eco-innovation wittingly or not, improve their firm marketing performance, this finding is supported the previous research carried out by Jogaratnam entrepreneurship orientation relies on the paradigm of entrepreneurs vis a vis the eco-innovation. In addition, entrepreneurship orientation also enhances their marketing performance [23]. This is in line with the previous study done by, since entrepreneurship orientation deals with the viable business practices in food industries in Central Java, Indonesia [20].

ICT learning adoption capability has significant impact on eco-innovation, this finding is supported by $[1,18,19]$. The ICT inevitably supports the dissemination of best practices of eco-innovation in food industries in Central Java since the actors are able to share knowledge, information and market access. Furthermore, the adoption of ICT enables food SMEs better access to wider markets and consumers. The ICT adoption in SMEs level needs adjustment and technical assistance from external actors such as universities, consultants etc.

The implementation of eco-innovation in food industries as a matter of fact has improved the marketing performance of the firms. However, some food innovation indicators such as energy efficiency, green food storage technology and green food network are considered weaker than other indicators such as green innovation and waste saving. They experience that the implementation of eco-innovation improves their business performance. This finding is supported by previous study done $[1,11]$.

\section{Conclusion}

All the hypotheses (entrepreneurship orientation, eco-innovation and ICT learning adoption capability) have significant impact on marketing performance. 
The authors would like to thank Direktorat Penelitian dan Pengabdian Masyarakat Kementerian Riset, Teknologi Dan Pendidikan Tinggi, Number of contract 026/L6/AK/PENELITIAN/2019 for granting the sponsorship of this study.

\section{References}

1. K. Lumbanbatu, V.D.W. Aryanto. Int. J. Soc. Ecol. Sust. Dev. 6,4:35-64(2015). https://www.igi-global.com/article/green-practices-implementation-as-prerequisite-tosustain-firm-competitive-advantages/142146

2. V.D.W. Aryanto, Y. Wismantoro, K. Widyatmoko. Int. J. E-Business Res. 14,1:2136(2018).

https://www.igi-global.com/chapter/implementing-eco-innovation-by-utilizing-theinternet-to-enhance-firms-marketing-performance/231242

3. A. Rauch, J. Wiklund, G.T. Lumpkin, M. ETP. 33,3:761-787(2009). https://journals.sagepub.com/doi/abs/10.1111/j.1540-6520.2009.00308.x

4. F. Zahra. Int. J. Mech. Eng. Technol. 8,6:822-830(2017).

https://www.google.com/url?sa=t\&rct=j\&q=\&esrc=s\&source=web\&cd=\&cad=rja\&ua $\mathrm{ct}=8 \& \mathrm{ved}=2$ ahUKEwjzqdzFitLqAhWEbSsKHU47CYoQFjAAegQIAhAB\&url=https $\% 3 \mathrm{~A} \% 2 \mathrm{~F} \% 2 \mathrm{Fwww}$. researchgate.net $\% 2 \mathrm{Fpublication} \% 2 \mathrm{~F} 318339323$ The impact of participative budgeting_on_budgetary_slack_A_metaanalysis\&usg=AOvVaw3O1KW2YkxRxcTezRfFex6d

5. I.R.E. Bagaria, E. Croft, A. Dentith, S. Feret, A. Nowack, M. Pancaldi, S. Valkama. Ecowaste 4 Food Interreg Europe. 3-11(2017).

https:/www.google.com/url?sa=t\&rct=j\&q=\&esrc=s\&source=web\&cd=\&cad=rja\&ua $\mathrm{ct}=8 \& \mathrm{ved}=2 \mathrm{ahUKEwj}$ TqcLUitLqAhUEQH0KHT3eBKQQFjABegQIARAB\&url=htt ps $\% 3 \mathrm{~A} \% 2 \mathrm{~F} \% 2 \mathrm{Fwww}$.interregeurope.eu\%2Ffileadmin $\% 2 \mathrm{Fuser}$.upload $\% 2 \mathrm{Ftx}$ _tevproj ects\%2Flibrary\%2Ffile_1505139758.pdf\&usg=AOvVaw0D5P0Z161gdZKF6iQIMpa $\underline{\mathrm{v}}$

6. J. Wiklund, D. Shepherd. J. Bus. Ventur. 20,1:71-91(2005).

https://www.google.com/url?sa $=t \& r c t=j \& q=\& e s r c=s \&$ source $=$ web $\& c d=\& c a d=r j a \& u a$ $\mathrm{ct}=8 \& \mathrm{ved}=2$ ahUKEwi659zfitLqAhXFfH0KHXvbCjoQFjAAegQIBhAB\&url=https\% 3A\%2F\%2Fwww.researchgate.net $\% 2$ Fpublication $\% 2 \mathrm{~F} 222269148$ Entrepreneurial_O rientation_and_Small_Business_Performance_A_Configurational_Approach\&usg=A OvVaw3ibmV_gxb9fjL_OIZcb7yS

7. P. Shan, M. Song, X. Ju. J. Bus. Res. 69,2:683-690(2016)

https://www.google.com/url?sa=t\&rct=j\&q=\&esrc=s\&source=web\&cd=\&cad=rja\&ua ct $=8 \& v e d=2$ ahUKEwiV-

L_pitLqAhVLWysKHU80D3cQFjAAegQIBRAB\&url=https\%3A\%2F\%2Fideas.repe c.org $\% 2 \mathrm{Fa} \% 2 \mathrm{Feee} \% 2 \mathrm{Fjbrese} \% 2 \mathrm{Fv} 69$ y2016i2p683-690.html\&usg=AOvVaw2p1jEq2fOP_U15I039wtF

8. G. Linton, K. Johan. J. Bus. Res. 70:168-176(2017).

https://www.google.com/url?sa $=t \& r c t=j \& q=\& e s r c=s \&$ source $=$ web $\& c d=\& c a d=r j a \& u a$ $\mathrm{ct}=8 \& \mathrm{ved}=2$ ahUKEwjCrofyitLqAhXYSH0KHZQ1CtkQFjAAegQIBBAB\&url=https $\% 3 \mathrm{~A} \% 2 \mathrm{~F} \% 2 \mathrm{Fideas}$.repec.org $\% 2 \mathrm{Fa} \% 2 \mathrm{Feee} \% 2 \mathrm{Fjbrese} \% 2 \mathrm{Fv} 70 \mathrm{y} 2017 \mathrm{icp} 168$ 176.html\&usg=AOvVaw3M-cyR-J9DcXdXWDew8JTs

9. M. Dayan, R. Zacca, Z. Husain, A. Benedito, J.C. Ryan. J. Bus. Ind. Mark. 31,5:668683(2016).

https://www.emerald.com/insight/content/doi/10.1108/JBIM-02-2015-0023/full/html

10. R. Kemp, P. Pearson. Policy Brief about Measuring Eco-Innovation. Sage Publication. 98-118(2008). https://www.osti.gov/etdeweb/biblio/21124989 
11. A.P. Gama, A.A. Hines. Mark. Intell. Plan. 29,7:643-661(2011). https://www.emerald.com/insight/content/doi/10.1108/02634501111178677/full/html

12. M. Yunis, A. Tarhini, A. Kassar. J. Bus. Res. 88:344-356(2018). https://www.sciencedirect.com/science/article/pii/S0148296317305246

13. E. Adamides, N. Karacapilides. J. Innov. Knowl. 90:2444-5691. (2018). https://www.google.com/url? sa $=$ t\&rct $=\mathrm{j} \& \mathrm{q}=\&$ esrc $=$ s\&source $=$ web $\& \mathrm{~cd}=\& v e d=2 \mathrm{ahU}$ KEwjLyaiymd3qAhWX63MBHdHtAWwQFjAAegQIAxAB\&url=https\%3A\%2F\%2 Ffardapaper.ir\%2Fmohavaha $\% 2$ Fuploads $\% 2$ F $2019 \% 2$ F $11 \% 2$ FFardapaperInformation-technology-for-supporting-the-development-and-maintenance-of-openinnovation-capabilities.pdf\&usg=AOvVaw29IJ7Dm_wb-iY-vqeKHU2S

14. F. Fatimah, D. Rosadi, R. Hakim. Neural Comput. Appl. 31,397-407(2019). https://ink.springer.com/article/10.1007/s00521-017-3011-y

15. C. Lechner, S.V. Gudmundsson. ISBJ. 32,1:36-60(2012). https://journals.sagepub.com/doi/abs/10.1177/0266242612455034

16. J.A. Zhang, F. Edgar, A. Geare, O’Kane. Ind. Mark. Manag. 59,131-143(2016). https://www.sciencedirect.com/science/article/pii/S0019850116300220

17. Y. Fernando, W.X. Wah. Sust. Prod. Consumption. 12:27-43(2017). https://www.sciencedirect.com/science/article/pii/S2352550917300155

18. P. Buttol, R. Bounamici, I. Naldesi, C. Rinaldi, A. Zamagni, P. Masoni. Clean Technol. Environ. Policy. 14,2:211-221(2012). https://link.springer.com/content/pdf/10.1007/s10098-011-0388-7.pdf

19. K.W.J. Green, P.J. Zlebst, V. Bhadauria, J. Meacham. Ind. Manag. Data Syst. 112,2:186-205(2012). https://www.emerald.com/insight/content/doi/10.1108/02635571211204254/full/html? queryID $=22 \% 2 \mathrm{~F} 5407253$

20. J. Alegre, K. Sengupta, R. Lapiedra. Int. Small Bus. J. 31,4:454-470(2013). https://journals.sagepub.com/doi/abs/10.1177/0266242611417472

21. P. Ritala, H. Olander, S. Michailova, K. Husted. Technovation. 35:22-31(2015). https://www.sciencedirect.com/science/article/pii/S0166497214001060

22. Y. Fernando, M.S. Shaharu, N.A. Wahid. Int. J. Serv. Oper. Manag. 23,1:43-58 (2016). https://www.inderscienceonline.com/doi/abs/10.1504/IJSOM.2016.073289

23. G. Jogaratnam. Int. J. Hospitality Manag. 60,104-113(2017). https://fardapaper.ir/mohavaha/uploads/2018/05/Fardapaper-The-effect-of-marketorientation-entrepreneurial-orientation-and-human-capital-on-positional-advantageEvidence-from-the-restaurant-industry.pdf

24. J. Hojnik, M. Ruzzier, T.S. Manolova. J. Cleaner Prod. 171, 1312-1323(2018). https://www.sciencedirect.com/science/article/pii/S0959652617324101 